\title{
ASSESSING LOSSES RELATED TO ACTUAL DISEASE INCIDENCE IN A REGION'S POPULATION: AN ECONOMIC ASPECT (A CASE STUDY OF ALTAI REGION OF RUSSIA) ${ }^{1}$
}

\author{
A.A. Ushakov, I.P. Saldan, O.I. Goleva, T.N. Karpova \\ The Altai Region Department of the Federal Service on Customers' Rights Protection \\ and Human Well-Being Surveillance, Russia, 656056, Barnaul, Altai Region, 28, \\ Gorkogo st., \\ Federal Budget Scientific Institution "Federal Scientific Center for Medical and \\ Preventive Health Risk Management Technologies”, Russia, 614045, Perm, 82, \\ Monastyrskaya st., \\ Federal State-Financed Educational Institution of Higher Professional Education \\ "Perm State National Research University", Russia, 614990, Perm, 15, Bukireva st
}

\begin{abstract}
In this article, we present the analysis of the economic losses associated with the actual disease incidence in the region's population by the following classes of diseases "Poisoning by drugs, medicaments and biological substances" (T36-T50) and "Toxic effects of substances chiefly nonmedicinal as to source" (T51-T65) which includes an assessment of production losses in the region's economy in value terms and an assessment of changes in cash flows in the RF budgets (tax revenues). The period of time covered by the analysis by the classes of diseases is 5 years (from 2007 to 2011). The greatest region's GRP losses related to the actual disease incidence in the population by classed of diseases T36-T50 and T51-T65 GRP over the analyzed time period occurred in 2011 more than 7 million rubles and were related to the actual disease incidence in men of working age (over 4 million rubles) and women of working age (more than 2 million rubles), the biggest income tax losses were observed in 2010 (more than 176 thousand rubles) with the share of the regional budget of $90 \%$, value added tax (VAT) losses in the region occurred in 2011 (more than 253 thousand rubles), the actual ratio of the paid VAT to the gross value added in the region in 2011 amounted to $3 \%$, the highest losses of personal income tax (PIT) were observed in 2011 (more than 22 thousand rubles). Thus, the greatest losses of tax revenues were in 2011 (more than 400 thousand rubles) and in 2010 (more than 427 thousand rubles).

Keywords: economic evaluation of VAT, income tax and GRP losses; actual disease incidence in the population by classes of diseases; time period covered by the analysis; production loss evaluation in value terms, evaluation of changes in cash flows in the RF budgets (tax revenues).
\end{abstract}

It is practical to assess the costs of a period of economic activity of the population (more specifically, reduction in the period) to the state (RF subject) by assessing the impact of the duration of the period of economic activity on the main social and economic indicators (GDP for the country and GRP for the region) through evaluating the change in the main financial flows including fiscal revenues and expenditures on various state levels, and revenues and expenditures of extrabudgetary funds [1].

Overall, assessment of the economic losses associated with the actual disease incidence (reduction in the period of economic activity) includes the following three components 2:

1) assessment of the undermanufactured product in the economy of a corresponding territory in value terms;

2) evaluation of the change in the financial flows in the RF budgets;

\footnotetext{
${ }_{2}^{1}$ Translated by Ksenya Zemnlyanova

2 The procedure to assess the period of incapacity to work developed by the Federal Budget Scientific Institution "Federal Scientific Center for Medical and Preventive Health Risk Management Technologies" of the of the Federal Service on Customers' Rights Protection and Human Well-Being Surveillance (Perm) is based on the best practices and approaches to the assessment theory adapted to the Russian reality with consideration for the specifics of the country's state of social services and statistical observation practices.
} 
3) evaluation of the change in the financial flows in the extrabudgetary funds of the RF (RF Pension Fund, Social Security Fund, Federal Compulsory Medical Insurance Fund, Local Compulsory Medical Insurance Fund).

While we can obtain actual data on the expenditures associated with the class of disease under review from the Social Security Fund and Federal Compulsory Medical Insurance Fund, assessment of the undermanufactured product and changes in the financial flows in the RF budgets (tax revenues) requires special approaches and methods [2]. This article focuses on those components of the economic assessment.

The assessment of economic losses in Altai Region associated with the disease incidence in the region's population by the following classes of diseases Poisoning by drugs, medicaments and biological substances" (T36-T50) and "Toxic effects of substances chiefly nonmedicinal as to source" (T51-T65) includes a monetary assessment of the reduction in the duration of the population's economic activity. The choice of the above classes of diseases is determined by the possibility of managing the health risks associated with those diseases by the local department of the Federal Service on Customers' Rights Protection and Human Well-Being Surveillance. The period of time covered by the analysis by the classes of diseases T36-T50 and T51-T65 is 5 years (from 2007 to 2011).

The suggested assessment of economic losses (reduction in the period of economic activity) associated with the actual disease incidence in the population in the classes of diseases under review includes the assessment of the undermanufactured product in the region's economy in value terms and evaluation of the change in the financial flows in the RF budgets (tax revenues).

The total (aggregate) period of the population's incapacity to work in the region in the classes of diseases T36-T50 and T51-T65 for the period of time under review is presented in the table below (Table 1).

Table 1

Total (aggregate) period of the population's incapacity to work in Altai Region in the classes of diseases T36-T50 and T51-T65 for 2007-2011, in percent of the year

\begin{tabular}{|c|c|c|c|c|c|c|c|}
\hline № & Age, years old & $\begin{array}{l}\% \text { of the year } \\
\text { under review }\end{array}$ & 2007 & 2008 & 2009 & 2010 & 2011 \\
\hline 1 & $0-14$ & 20 & 1.06 & 1.05 & 0.95 & 0.95 & 0.83 \\
\hline 2 & 18-55 (women) & 100 & 10.41 & 9.26 & 9.13 & 7.25 & 7.23 \\
\hline 3 & 18-60 (men) & 100 & 15.02 & 12.96 & 11.73 & 12.79 & 12.51 \\
\hline 4 & 56 and older (women) & 20 & 0.77 & 0.68 & 0.76 & 0.74 & 0.81 \\
\hline 5 & 61 and older (men) & 20 & 0.48 & 0.45 & 0.43 & 0.65 & 0.58 \\
\hline \multicolumn{3}{|c|}{ TOTAL: } & 27.74 & 24.41 & 23.00 & 22.37 & 21.96 \\
\hline
\end{tabular}

Table 1 shows that the longest period of incapacity to work is among the men of working age (18-60 years old). The share of this group totaled in $2007-52.4 \%$, in $2008-53.1 \%$, in $2009-51.0 \%$, in $2010-57.2 \%$, in $2011-57.0 \%$. The longest period of incapacity to work

${ }^{3}$ - since the calculations are based on the length of the period of incapacity to work, the result is taken into account for the percent of cases resulted in incapacity to work for the working population (including the parents with sick children). The percentage is calculated based on the statistical data for the previous period. 
was in 2007; in that year, the number of acute poisonings related to chemical substances in the population exceeded the value of 2008 onward (per 10 thsd. population) $-22.960 / 000,21.85$ 0/000, $21.660 / 000,21.030 / 000,18.77$ 0/000 respectively.

The region's estimated GRP losses per employee per year of incapacity to work in the class of diseases T36-T50 and T51-T65 for the period under review are presented in Table 2.

Table 2

GRP losses associated witht the actual incidence in the classes of diseases T36-T50 and T51-T65 in Altai Region for 2007-2011, RUB

\begin{tabular}{|c|c|c|c|c|c|c|}
\hline № & Age, years old & 2007 & 2008 & 2009 & 2010 & 2011 \\
\hline 1 & $0-14$ & 214395 & 247818 & 236142 & 271662 & 266998 \\
\hline 2 & $18-55$ (women) & 2100826 & 2178560 & 2278015 & 2083107 & 2341111 \\
\hline 3 & $18-60$ (men) & 3031271 & 3048437 & 2928193 & 3674358 & 4048411 \\
\hline 4 & 56 and older (women) & 155019 & 158640 & 189652 & 211065 & 263098 \\
\hline 5 & 61 and older (men) & 96306 & 106705 & 108021 & 186039 & 187218 \\
\hline TOTAL: & 5597817 & 5740160 & 5740024 & 6426231 & 7106837 \\
\hline
\end{tabular}

Table 2 shows that the region's biggest estimated GRP losses per employee per year of incapacity to work in the classes of diseases T36-T50 and T51-T65 took place in 2011 (7 106.8 thsd. RUB) exceeding the values of 2007, 2008, 2009 and 2010 by 1.3, 1.2, 1.2 and 1.1 times respectively.

Specifics of the calculation of GRP result in the fact that the input of 1 employee in one industry in the total volume of GRP in one year will significantly differ from the input of 1 employee in a different industry (temporary incapacity of an employee working in different industries will have a different impact on GRP).

Review of the region's main industries (Table 3) shows that in 2011 the following industries experienced the biggest economic losses (based on the Russian National Classifier of Economic Activities): Manufacturing (a 2.9 increase in GRP losses in 2011 as compared to 2007) and Agriculture ( a 2.9 increase in GRP losses in 2011 as compared to 2007), Wholesale Trade and Retail (a 1.6 decrease in GRP losses in 2011 as compared to 2007), State Administration of Government (a 1.7 increase in GRP losses in 2011 as compared to 2007), Property Operations (a 1.1 increase in GRP losses in 2011 as compared to 2007), Manufacturing and Distribution (a 2.2 increase in GRP losses in 2011 as compared to 2007), Transportation and Communication (GRP losses in 2011 are equal to the 2007 value). 
Table 3

The region's estimated gross regional product losses per employee per year of incapacity to work in the classes of diseases T36-T50 and T51-T65 in Altai Region for 2007-2011, thsd RUB

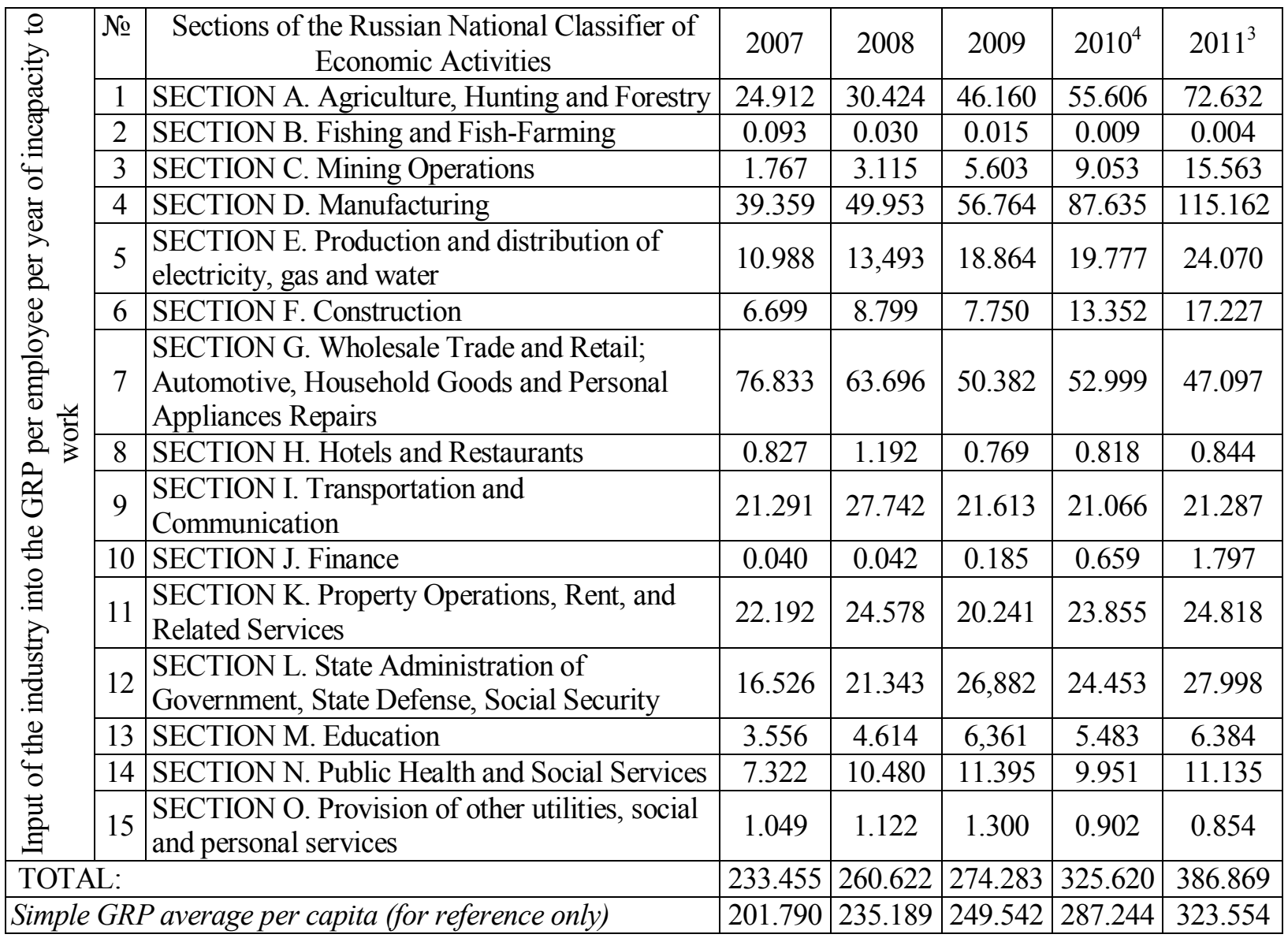

Calculated based on the data [3-5].

Table 4 shows that the region's biggest losses in GRP associated with the actual disease incidence in the classes of diseases T36-T50 and T51-T65 for the period of time under review took place in 2011 - over 7 mln RUB - which is related to the actual disease incidence in men (over $4 \mathrm{mln}$ RUB) and women (over $2 \mathrm{mln}$ RUB) of working age; biggest losses in income tax took place in 2010 (over 176 thsd. RUB) of which the share of the regional budget totaled $90 \%$; biggest losses in the region's VAT taxex took place in 2011 (over 253 thsd. RUB); actual ratio of the amount of VAT paid to the gross value added in the region this year totaled $3 \%$; biggest losses in the region's personal income taxes took place in 2011 (over 22 thsd. RUB). As a result, the biggest losses in tax income took place in 2011 (over 400 thsd. RUB) and 2010 (over 427 thsd. RUB).

${ }^{4}$ - forecast on the average annual GRP growth rate in the region. The values of losses associated with the actual disease incidence in the population in the region in the classes of diseases T36-T50 and T51-T65 for the period under review (Table 4). 
Table 4

Economic losses associated with the actual disease incidence in the population of Altai Region in the classes of diseases T36-T50 and T51-T65 in 2007-2011, RUB

\begin{tabular}{|c|c|c|c|c|c|c|c|}
\hline № & \multicolumn{2}{|r|}{ Indicator } & 2007 & 2008 & 2009 & 2010 & 2011 \\
\hline 1 & \multicolumn{2}{|c|}{$\nabla \simeq \propto$ Losses in GRP } & 5597817 & 5740160 & 5740024 & 6426231 & 7106837 \\
\hline \multirow{4}{*}{2} & \multirow{4}{*}{ 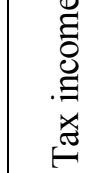 } & Losses in income tax & 99475 & 97703 & 78233 & 176292 & 132137 \\
\hline & & Losses in VAT, RUB & 145861 & 125500 & 103852 & 230668 & 253197 \\
\hline & & Losses in personal income tax & 16753 & 18601 & 18492 & 20188 & 22735 \\
\hline & & TOTAL (losses in tax income) & 262089 & 241804 & 200577 & 427148 & 408069 \\
\hline
\end{tabular}

Calculated based on the data [3-6].

The use of this evaluation procedure by the Federal Service on Customers' Rights Protection and Human Well-Being Surveillance can become a helpful tool in providing grounds for the decisions regarding funding the activities aimed at lowering the health risks.

\section{References:}

1. Zajceva N.V., Shur P.Z., Goleva O.I. Jekonomicheskaja ocenka riska dlja zhizni i zdorov'ja naselenija regiona [An economic assessment of risks to life and health in the region's population]. Jekonomika regiona, Ekaterinburg: Institut jekonomiki UrO RAN, 2012, no. 2 (30), pp. $178-186$.

2. Goleva O.I. Ocenka izmenenij denezhnyh potokov po bjudzhetam RF v jekonomicheskoj ocenke sokrashhenija perioda jekonomicheskoj aktivnosti naselenija, svjazannoj s riskom dlja zdorov'ja naselenija [An assessment of changes in cash flows in the RF budgets in the economic evaluation of the reduction in the period of the economic activity of the population, related to the risk to human health]. Sovremennye problemy upravlenija riskom: materialy Mezhdunarodnoj zaochnoj nauchno-prakticheskoj konferencii studentov, aspirantov i molodyh uchenyh (20 oktjabrja 2010 g., Perm'). Perm', 2010.

3. Oficial'nyj sajt federal'noj sluzhby gosudarstvennoj statistiki [Oficial'nyj sajt federal'noj sluzhby gosudarstvennoj statistiki]. Available at: http: //www.gks.ru.

4. Altajskij kraj v cifrah [The Altai Region in figures]. Available at: http://ak.gks.ru.

5. Statisticheskij ezhegodnik Altajskogo kraja [An annual statistical book of the Altai Region]. Available at: http://ak.gks.ru.

6. Otchety o postuplenii nalogovyh platezhej v bjudzhetnuju sistemu RF po osnovnym vidam jekonomicheskoj dejatel'nosti po godam (po forme № 1-NOM) [Annual reports on tax payments to the RF budget system according to the main types of economic activities (form no. 1-NOM)]. Available at: http://www.r22.nalog.ru. 


\section{A b o ut the a uthors:}

Ushakov Alexandr Anatolyevich, PhD in Medicine (Barnaul, Russia) - Head of the Social and Hygiene Monitoring Department, the Altai Region Region Department of the Federal Service on Customers' Rights Protection and Human Well-Being Surveillance (28 Gorkogo St, Barnaul, 656056, Altai Region, email: Ushakov_AA@22.rospotrebnadzor.ru; tel.: 8 (385) 2-2484-88; mobile: 8-961-979-44-87).

Saldan Igor Petrovich, DSc in Medicine (Barnaul, Russia) - Head of the Altai Region Region Department of the Federal Service on Customers' Rights Protection and Human WellBeing Surveillance (28 Gorkogo St, Barnaul, 656056, Altai Region, email: Saldan_IP@22.rospotrebnadzor.ru; tel.: 8 (385) 2-24-29-96).

Goleva Olga Ivanovna, PhD in Economics (Perm, Russia) - Senior Lecturer, the Federal State-Financed Educational Institution of Higher Professional Education "Perm State National Research University" (15 Bukireva St, Perm, 614990); Specialist on Risk Assessment, the Federal Budget Scientific Institution "Federal Scientific Center for Medical and Preventive Health Risk Management Technologies" (82 Monastyrskaya St, Perm, 614045, email: GolevaOlga@inbox.ru, tel.: 89028371595.

Karpova Tatiana Nikolaevna (Barnaul, Russia) - Chief Specialist-Expert of the Arkhangelsk Region Department of Social and Hygiene Monitoring Department, the Altai Region Region Department of the Federal Service on Customers' Rights Protection and Human Well-Being Surveillance (28 Gorkogo St, Barnaul, 656056, Altai Region, email: Karpova_TN@22.rospotrebnadzor.ru, tel. (fax): 8 (385) 224-84-88). 